\title{
FDI Trend and Its Contribution Toward Labor Absorption in East Java
}

\author{
Citra Fatimah Nur $^{\mathrm{a}} *$ \\ ${ }^{a}$ East Java Investments Agency and Integrated Licence Services, Surabaya, East Java, Indonesia
}

\section{INFORMASI ARTIKEL}

\section{Article history:}

Date Submission: 12 July 2019

First revision: 26 October 2019

Accepted: 17 December 2019

Available online: 26 December 2019

Keywords: FDI, labor absorption, panel data regression, East Java

\section{ABSTRACT}

This study aims to examine and analyze the effect of investment through number of FDI project and amount of FDI capital toward labor absorption and its trend and distribution at East Java Province in Indonesia. The study period was eighteen years from 2000 to 2017 by using secondary data of Principal License issued by Indonesia Investment Board in the form of combination between times series data and crosssectional data (5 cities/regencies in East Java) also known as panel data. Hypothesis testing in this study is conducted by using Panel Data Regression Model under Eviews 7. Test of 2 (two) hypothesis with level of significance $\alpha=0.05$ obtained the following results: First, amount of FDI capital has a positive but not significance effect on labor absorption. Second, number of FDI project has a positive and significance effect on labor absorption. The distribution of FDI in East Java still in disparity, only spread in some big cities/regencies (Surabaya, Sidoarjo, Gresik, Pasuruan and Mojokerto) with sector preference about secondary industry such as chemical industry, metal industry, food industry, other industry and trade and reparation.

\section{INTISARI}

Penelitian ini bertujuan untuk menguji dan menganalisis pengaruh investasi melalui jumlah proyek FDI dan jumlah modal FDI terhadap penyerapan tenaga kerja dan tren serta distribusinya di Provinsi Jawa Timur di Indonesia. Periode penelitian adalah delapan belas tahun dari Tahun 2000 hingga 2017 dengan menggunakan data sekunder izin pokok yang dikeluarkan oleh Badan Investasi Indonesia dalam bentuk kombinasi antara data seri waktu dan data cross-sectional (5 kota/ kabupaten di Jawa Timur) yang juga dikenal sebagai data panel. Pengujian hipotesis dalam penelitian ini dilakukan dengan menggunakan Panel Data Regression Model di bawah Eviews 7. Uji 2 (dua) hipotesis dengan tingkat signifikansi $\alpha=0,05$ diperoleh hasil sebagai berikut: Pertama, jumlah modal FDI memiliki pengaruh positif tetapi tidak signifikan terhadap penyerapan tenaga kerja. Kedua, jumlah proyek FDI memiliki efek positif dan signifikan terhadap penyerapan tenaga kerja. Distribusi FDI di Jawa Timur masih dalam kesenjangan, hanya menyebar dibeberapa kota/ kabupaten besar (Surabaya, Sidoarjo, Gresik, Pasuruan, dan Mojokerto) dengan preferensi sektoral tentang industri sekunder seperti industri kimia, industri logam, industri makanan, industri lain dan perdagangan dan reparasi. 


\section{Introduction}

Carrying out national development, a developing country, Indonesia needs substantial funds in this global era. Such a large funding needs occured as a result of catching up the development from developed countries, both in the regional and global regions. Indonesia still not able to provide the development funds. Besides trying exploring domestic financing sources, the government also invited sources foreign financing, one of which is Foreign Direct Investment.

The source of this financing, FDI, seen by some observers as a source the most potential foreign financing compared to other sources. Panayotou (1998) explains that FDI is more important in guaranteeing continuity of development compared to the flow of aid or capital portfolio, because the occurrence of FDI in a country will be followed by a transfer of technology, know-how, management skills, business risks are relatively small and more profitable. Further research by Panayotou (1998) stated that more than $80 \%$ Private capital and $75 \%$ of FDI since 1990 flowed to countries with middle income countries. For the Asian region the value reached $60 \%$ and America Latin by 20\%. Another researcher, Sulistiawati (2012) found that investment has a positive and significance effect on labor absorption. And Syaihu (2012) depicted that there were direct influence between foreign investment and domestic investment to employment opportunities and unemployment in East Kalimantan. And recent findings posed by Riti et al., (2016) investigated the relationship between FDI inflows, manufacturing export and the environment. The study focused in Nigeria, explained that there was positive relation among pollution haven, manufacturing exports by the existence of FDI toward emission rate. They recommended green investment movement by not only corcerning on attracting FDI of oil industries whichproduce large sum of emissions but also to other sectors which have more environment friendly.

East Java as part of Indonesia which located in the center of Indonesia tends to attract FDI as one of the way for sustaining economic growth and moreover providing ocupation to the citizens. According to Invesment Board Realization press release of first semester in 2018, East Java's FDI realization came at 8th rank after West Java, Jakarta, Banten, Central Java, South Sumatra, Riau and Papua (BKPM RI, 2018). This rank condition decrease from the same period in previous year. As previous findings showed that FDI not only affected in economic growth in a region, but also to the labor absorption, it is an urge to investigate the dropped rank of FDI realization as one of the way for sustaining labor absorption, especially in some cities/regencies which have high wages such as Surabaya, Sidoarjo Regency, Pasuruan Regency, Gresik Regency, and Mojokerto Regency.

The objective of this thesis is to analyze the current trend of FDI in East Java represented by five cities/ regencies, it's distribution and whether it has strong contributions to Labor Absorption. Moreover, if its beneficially contribute, we may predict the next model of FDI using panel data regression.

\section{Theory}

According to Todaro (2000) investment plays an important role in driving the nation's economic life, because capital formation increases production capacity, national income and creates new jobs, furthermore it will expand employment opportunities. Moreover, Keynes in Jhingan (2003) emphasizes the importance of aggregate demand or effective demand as the main factor driving the economy, where both the state and the private sector play an important role. Keynes views the government as an independent agent which capable of stimulating the economy through public work. Expansionary government policies can increase "effective demand" if the resources are used without harming consumption or investment. This keynes theory, been revised later by Harrod - Domar in Arsyad (2010) by giving a key role to investment in the process of economic growth, especially regarding the dual nature of investments. First, investment creates income (the impact of investment demand), and secondly, investment increases economic production capacity by increasing capital stock (the impact of investment offers). Solow \& Swan in Arsyad (2010) then corrected Harrod-Domar's theory by showing that economic growth depends on the availability of factors of production (population, labor, and capital accumulation) and the level of technological progress. The assumption used is a constant scale of return (constan return to scale), the substitution between capital (K) and labor (L) is perfect, and the marginal productivity decreases (diminishing marginal productivity) of each input.

According to Todaro (2000), the labor economy model related to investment, economic growth and labor absorption is a Model of Macro Output - an outputemployment macro model that focuses on the relationship between capital accumulation, industrial output growth, and creation employment. The main concern of this growth model is the policy to increase national output through capital accumulation. This model connects the level of employment opportunities with the GNP growth rate, so this model implies that by maximizing its GNP growth, a country can maximize employment. 
By focussing on FDI existence, based on those theoretical frameworks, the conceptual model in this study can be described as:

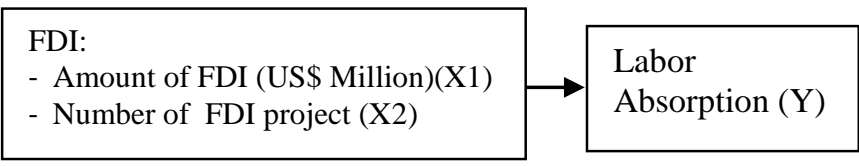

Figure 1 Theoretical Framework

Source: Analytical result, 2019

\section{Research Method}

In this work, at first we will describe current trend of the FDI in East Java with simple line graph from 2000 2017 then we will explain about its distribution throughout East Java cities/regencies by its sector preference, and the last panel data analysis will be used in order to study the link between FDI, Number of Project, and Labor absorption in 5 cities/regencies in East Java which is known as ring 1 in the amount of wages (Surabaya, Sidoarjo, Pasuruan Regencies, Mojokerto Regencies, Gresik Regencies) with hypothesis:

$\mathrm{H} 1$ : There is significant influence of the amount of FDI to the labor absorption in East Java

$\mathrm{H} 2$ : There is significant influence of the number of FDI project to the labor absorption in East Java

The metadata that will be used in this work can be described as below:

Table 1 Research Metadata

\begin{tabular}{|c|c|c|}
\hline Model & Indicators & Variables \\
\hline $\begin{array}{ll}\text { Total } & \text { FDI } \\
\text { vs } & \text { Labor } \\
\text { Absorption }\end{array}$ & $\begin{array}{l}\text { - } \text { Total FDI } \\
\text { Investment } \\
\text { - Total FDI } \\
\text { Project } \\
\text { - Total FDI } \\
\text { absorbed } \\
\text { labor }\end{array}$ & $\begin{array}{l}\text { - Total amount of } \\
\text { FDI in each cities } \\
\text { and regencies } \\
\text { (million US\$) } \\
\text { - Total number of } \\
\text { FDI project in each } \\
\text { cities and regencies } \\
\text { (project) } \\
\text { - Total number of } \\
\text { absorbed labor } \\
\text { within FDI in each } \\
\text { cities and regencies } \\
\text { (persons) }\end{array}$ \\
\hline
\end{tabular}

Source: Analytical result, 2019

Those number taken from total FDI investment amount and labor absorbed by the companies based on principle license published by BKPM in $2000-2017$.

The empirical treatment involves the applications of panel estimation procedures. The independent variable is FDI. And, the dependent variables that are expected to explain the problem is about number of labor absorption by each categories of FDI. All the variables are expressed in natural logarithm. In connection with discussions of the previous section, we propose specification as follow, where the selected variables are expected to determine the FDI:

LnLabit=a0+b1LnFDIit+b2LnPFDIit+eit

Where, $\mathrm{i}$ and $\mathrm{t}$ represent respectively the cities/ regencies index, and the time index.

- Ln Labit is the log natural of total labor absorption for cities/regencies $i$ at time $t$.

- Ln FDIit is the log natural of FDI in current million US\$ for cities/ regencies $i$ at time $t$.

- Ln PFDIit is the log natural of FDI Project in current number for cities/regencies $i$ at time t.

- eit is the standard error which is assumed to be white noised and varies over both cities/ regencies and time.

\section{Results and Discussion}

In this part, the data calculation is explained to answer the research questions. Begin with the descriptive statistics of existing FDI trend toward labor absorption and its distribution within sectors and cities/regencies in East Java.

\subsection{Descriptive Analysis}
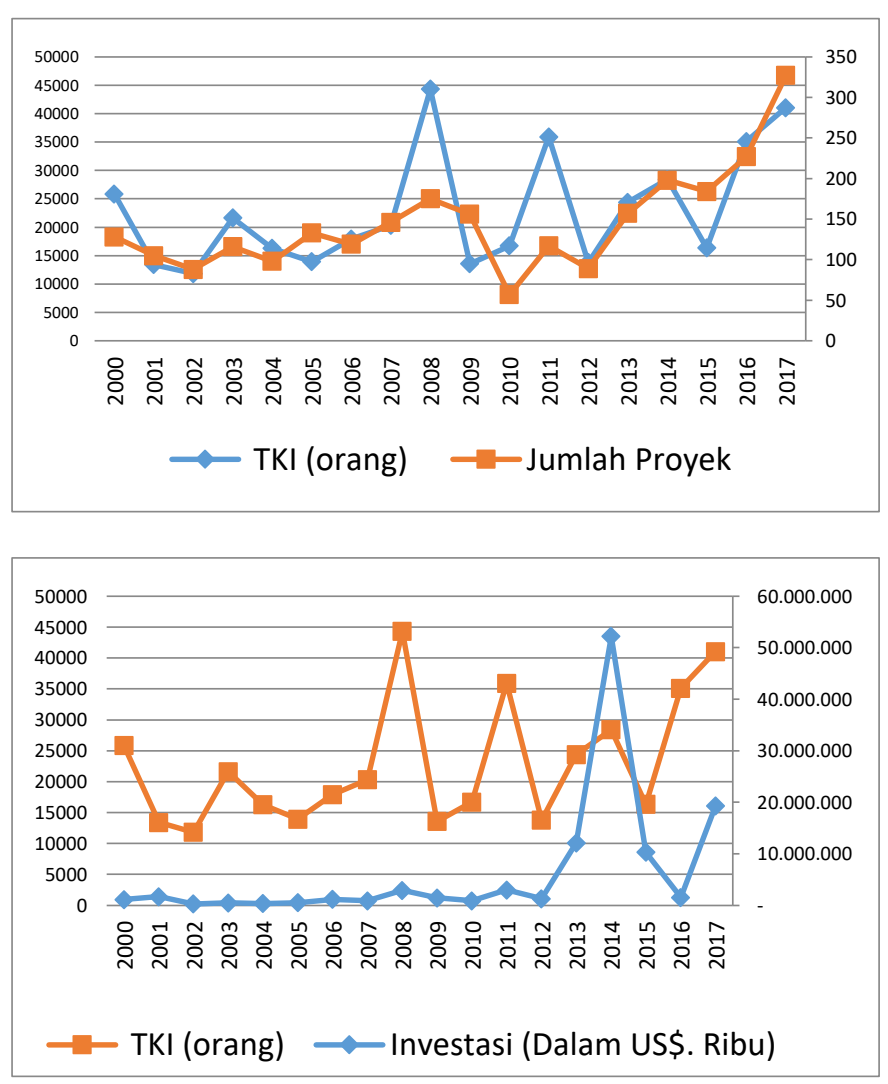

Figure 1 East Java FDI trend, 2000-2017

Source: Constructed by the author from BKPM RI database, 2019

The trend distribution of Labor absorption versus amount of FDI capital in 2000 -2017 show that the linier graph pattern didn't indicate in line graph. The fluctuation of the capital during 2000 - 2012 not really significant, while the labor absorption year on year 
fluctuated prominently. In contra, the trend distribution of Labor absorption versus number of FDI project in 2000-2017 show that they are liniery distributed. The fluctuation of both labor absorption and number of FDI project are coincide prominently year by year.

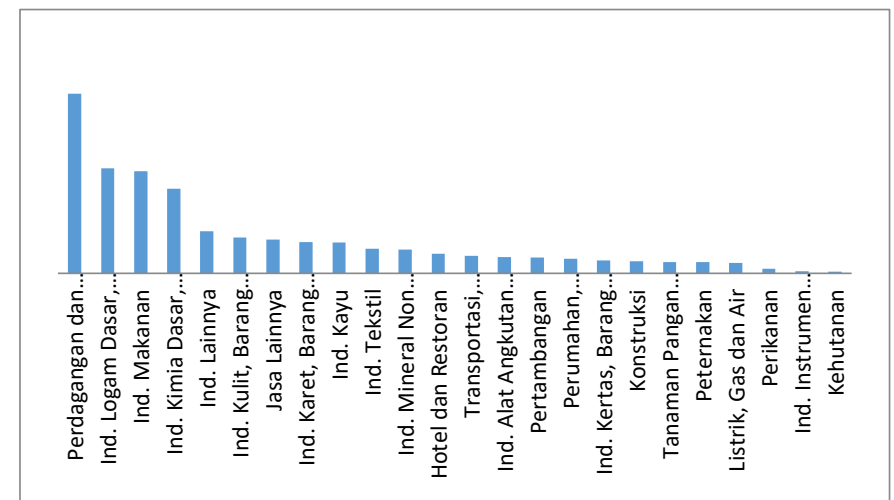

Figure 2 East Java FDI distribution by sector preference, 2000-2017

Source: Constructed by the author from BKPM RI database, 2019

Based on number of FDI project, the FDI distribution by sector were dominated by secondary sector which are metal industry, food industry, trade and reparation, chemical industry, and other industry. Metal industry in Sidoarjo Regency, food industry and other industry in Pasuruan Regency, while chemical industry and trade and reparation dominantly grew in Surabaya.

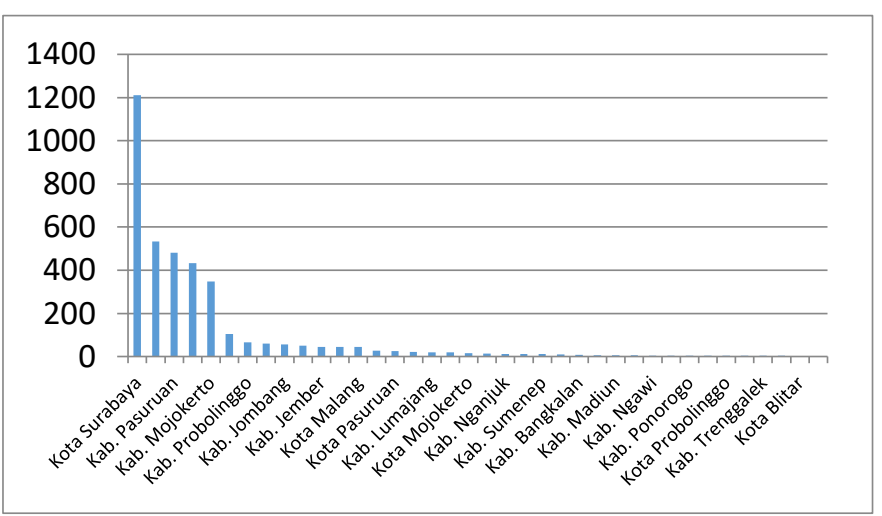

Figure 3 East Java FDI distribution by location preference, 2000-2017

Source: Constructed by the author from BKPM RI database, 2019

From the histogram, we can conclude that 5 most popular cities/ regencies prefered by foreign investor still inside the ring 1, which are Pasuruan Regencies, Surabaya, Sidoarjo, Mojokerto Regencies, Gresik Regencies with labor absorption.

\subsection{Regression Results}

\subsubsection{Classical Assumption Test}

In every single Regression analysis, the data used in the calculation should meet four regression classical assumption test which are exempt from multicolinierity, heterokedasticity, autocorrelation and the residual normally distribute. After those four assumption clearly accepted, panel data regression can be computed through common effect model, fixed effect model and random effect model. And the last, finding out the best model from three model applied.

\subsubsection{Autocorrelation}

Hypothesis:

H0 : There is connection within residual (There is autocorrelation problem)

H1 : There is no connection within residual (There is no autocorrelation problem)

Using Breusch-Godfrey serial correlation LM test computed from Eviews 7, the Prob. Chi-Square value is $0.7357>0.05$, we can conclude that the hypothesis is reject $\mathrm{H} 0$. It means that there is no autocorrelation event in this case.

\subsubsection{Heterocedasticity Test}

Heteroscedasticity is residual characteristic which has heterogen variance or can be defined mathematically. This condition can be treasured by analyzing scatterplot between residual. In SPSS, the result of this case residual scatterplot, but in Eviews we can compute through many tests, one of them is Breusch-Pagan-Godfrey test.

Hypothesis:

$\mathrm{HO}: \quad$ (There is Heteroscedasticity problem)

H1 : (There is no Heteroscedasticity problem)

Using Breusch-Godfrey heteroskedasticity test computed from Eviews 7, the Prob. Chi-Square value is $0.8014>0.05$, we can conclude that the hypothesis is reject H0. It means that there is no more heterokedasticity event in this case.

\subsubsection{Multicolinierity Test}

Hypothesis:

$\mathrm{H} 0$ : There is no multicolinierity problem

$\mathrm{H} 1$ : There is multicolinierity problem

VIF value $=1,220389<10$, so the conclusion is accept $\mathrm{HO}$ which is there is no multicolinierity problem in this case.

\subsubsection{Normal Distribution Test}

A low significance value (generally more than 0.05 ) indicates that the distribution of the data is significantly from a normal distribution. With Jarque-Bera value test 2.552618 and probability 0.279065 denote that this residual normally distributed.

\subsection{Parameter Estimation}

In panel data regression, the model can be computed in several models which are common effect model, fixed effect model and random effect model. In this study, all three models are computed and best suit model choosen is random effect model. 


\subsubsection{Common Effect Model}

This model derived similarly to the OLS (ordinary least square) principle, which is not heed the timeseries and cross section part of the data.

The panel data regression with common effect model can be built as:

Log Labit $=5.809026+0.028354$ Log FDIit + 0.542188 Log PFDIit + eit

Which can be intepret as:

In addition of 1 point of FDI value, the labor absorption will be increase by the point of 0.302499 . However, the increasing number of FDI project by 1 point can affect the increasing number of labor absorption by 0.785923. Partial test Simultant test of coefficient regression hypothesis:

H0 : $\quad b k=0$ (model with common effect approach is not significant)

H1 : $\quad b k \neq 0$ (model with common effect approach is significant)

From the Eviews output common effect model, we can indicate from the prob F-statistic value $=0.000049$ which is smaller than $\alpha(0.05)$ so the conclusion of simultant test is reject $\mathrm{H} 0$, that this model can significantly accepted.

Partial test of coefficient regression hypothesis

$\mathrm{H} 0: \mathrm{bi}=0$

$\mathrm{H} 1: \mathrm{bi} \neq 0$

From the Eviews output common effect model, we can indicate from the prob value of $b 1=0.6362$ which is bigger than $\alpha(0.05)$ so the hypothesis for $b 1$ is accept $\mathrm{H} 0$. In other hand, prob value of b0 and b2 are 0.0000 and 0.0001 respectively. So, the conclusion for $b 0$ and $b 2$ is reject $\mathrm{H} 0$. It can be assumed that only number of project significantly effected to the labor absorption.

\subsubsection{Fixed Effect Model}

The panel data regression with fixed effect model can be built as:

Log Labit $=5.214297+0.041455$ Log FDIit + 0.693474 Log PFDIit + eit

Which can be intepret as:

In addition of 1 point of FDI value, the labor absorption will be increase by the point of 0.041455 . However, the increasing number of FDI project by 1 point can affect the increasing number of labor absorption by 0.693474 .

Simultant test of coefficient regression hypothesis:

H0 : $\quad b k=0$ (model with common effect approach is not significant)

H1 : $\quad b k \neq 0$ (model with common effect approach is significant)

From the Eviews output common effect model, we can indicate from the prob F-statistic value $=0.000046$ which is smaller than $\alpha(0.05)$ so the conclusion of simultant test is reject $\mathrm{H} 0$, that this model can significantly accepted.

Partial test of coefficient regression hypothesis:

$\mathrm{H} 0: \mathrm{bi}=0$

$\mathrm{H} 1: \mathrm{bi} \neq 0$

From the Eviews output common effect model, we can indicate from the prob value of $b 1=0.5153$ which is bigger than $\alpha(0.05)$ so the hypothesis for $\mathrm{b} 1$ is accept $\mathrm{H} 0$. In other hand, prob value of b0 and b2 are 0.0000 and 0.0002 respectively. So, the conclusion for $\mathrm{b} 0$ and $\mathrm{b} 2$ is reject $\mathrm{H} 0$. It can be assumed that both CEM and FEM results that only number of project significantly effected to the labor absorption.

\subsubsection{Random Effect Model}

The panel data regression with random effect model can be built as:

Log Labit $=5.539294+0.037926$ Log FDIit + 0.596377 Log PFDIit + uit +eit

Which can be intepret as:

In addition of 1 point of FDI value, the labor absorption will be increase by the point of 0.037926 . However, the increasing number of FDI project by 1 point can affect the increasing number of labor absorption by 0.596377 .

Simultant test of coefficient regression hypothesis:

HO : $\quad b k=0 \quad$ (model with common effect approach is not significant)

H1 : $\quad b k \neq 0 \quad$ (model with common effect approach is significant)

From the Eviews output common effect model, we can indicate from the prob F-statistic value $=0.000029$ which is smaller than $\alpha(0.05)$ so the conclusion of simultant test is reject $\mathrm{H} 0$, that this model can significantly accepted.

Partial test of coefficient regression hypothesis

$$
\mathrm{H} 0: \mathrm{bi}=0
$$$$
\mathrm{H} 1: \mathrm{bi} \neq 0
$$

From the Eviews output random effect model, we can indicate from the prob value of $\mathrm{b} 1=0.5296$ which is bigger than $\alpha(0.05)$ so the hypothesis for b1 is accept $\mathrm{H} 0$. In other hand, prob value of b0 and b2 are 0.0000 and 0.0001 respectively. So, the conclusion for $b 0$ and $b 2$ is reject $\mathrm{H} 0$. It can be assumed that all approach results that only number of project significantly effected to the labor absorption.

\subsection{Best Model Selection}

From the Eviews output prob. Chi-Sq of Chow Test show the value $=0.0001$ which is less than $\alpha(0.05)$ so the conclusion is Fixed Effect Model better than common effect model. Then, we continue to test using Hausman Test to choose between fixed effect model or random effect model. 
While, the Hausman Test show the value of prob. $\mathrm{Chi}-\mathrm{Sq}=0.1654$ which is bigger than $\alpha(0.05)$ means that Random Effect Model better than Fixed effect model. In conclusion, the best suit data panel regression model of this case is using Random Effect Model with R-Sq = $20.14 \%$.

Log Labit $=5.539294+0.037926$ Log FDlit + 0.596377 Log PFDIit + uit +eit

\section{Conclusion}

Developing countries may deliberately craft standard measures The results that can be taken from data analysis using Random Effect Model of Data Panel Regression is number of FDI project significantly influences to the labor absorption in five cities/regencies in East Java, while amount of FDI didn't significantly influences. Based on Keynes Theory and Economic Model, FDI is part of determinant factor that influence to the labor absorption, but through this paper it is found that the FDI number of project is the determining key to labor absorption, not the amount of FDI investment. It can be assumed that the government should attract many FDI investor even though they have low or high capital rather than attracting a few FDI investor with high capital. It is reasonable, as FDI investor tend to use high technology requiring high amount of capital to import from other/ home country.

Based on the result of the analysis above considering the effect of FDI (number of project and amount of capital) to the labor absorbtion in five cities/ regencies of East Java, can be concluded as:

a) The trend distribution of Labor absorption versus amount of FDI capital in $2000-2017$ show that the linier graph pattern didn't indicate in line graph. The fluctuation of the capital during 2000 - 2012 not really significant, while the labor absorption year on year fluctuated prominently;

b) The trend distribution of Labor absorption versus number of FDI project in 2000 -2017 indicate that they are liniery distributed. Both of the line graph pattern fluctuated prominently year by year;

c) The FDI distribution by sector dominated by secondary sector which are metal industry, food industry, trade and reparation, chemical industry, and other industry. Metal industry in Sidoarjo Regency, food industry and other industry in Pasuruan Regency, while chemical industry and trade and reparation dominantly grew in Surabaya;

d) As for location preferences, five cities/ regencies which have highest labor wages still choosen by foreign investor. Indeed they need more cost on labor but this five cities/ regencies have sustainable infrastructure and facilities that support in investment, such as industrial estates, advance integrated license service and interconnection toll road, harbour and railway;

e) Actually based on simultant test on data panel regression model, FDI significantly influenced to the labor absorbtion in five cities/ regencies of East Java;

f) The best model suitable used for this case is random effect model of data panel regression with R-sq 20.14\% and model: $\log$ Labit $=5.539294+0.037926$ Log FDIit + 0.596377 Log PFDIit + uit +eit;

g) The best recommendation can be given from the findings of this research is the government should attract many FDI investor with both low or high capital with labor intensive rather than attracting a few FDI investor with high capital inflow;

h) Investment policy regarding investment acceleration should be applied to incline ease of doing business rank, so that many investors become optimist to invest in Indonesia especially East Java;

i) Moreover, the infrastructure development in East Java should be spread evenly, especially toll road, harbour and railway. Also, giving facilitation toward investor who want to build industrial estates in cities/regencies which didn't have industrial estates or should government develop new industrial estates through stated owned enterprises in potential cities/regencies in East Java; dan

j) As this study main focus is only FDI effect to labor absorption, recommendation for the next study may use other factor such as infrastructure and license service quality to make it more comprehensive.

\section{Reference}

Arsyad, L. (2010). Ekonomi Pembangunan. Yogyakarta: UPP STIM YKPN.

BKPM RI. (2018). Domestic and Foreign Direct Investment Realization in Quarter II 2018. Available

at

https://www.bkpm.go.id/en/publicator/pressrelease/readmore/1247001/31101 [Accessed on 16 September 2018].

Jhingan, M. L. (2003). Ekonomi Pembangunan dan Perencanaan. Jakarta : PT. Raja Grafindo Persada.

Panayotou, Theodore. (1998). Investments of Change: Motivating and Financing Sustainable Development. Earthscan Publications, London.

Riti, J., Sentanu, IGEPS., Cai, A., \& Syeikh, S. (2016). Foreign Direct Investment, Manufacturing Export and the Environment in Nigeria: A Test of Pollution Haven Hypothesis. NIDA Development Journal, Vol. 56, No. 2, pp.73-98.

Sulistiawati, R. (2012). Pengaruh Investasi terhadap Pertumbuhan Ekonomi dan Penyerapan Tenaga Kerja Serta Kesejahteraan Masyarakat di Provinsi 
di Indonesia. Jurnal Ekonomi Bisnis dan Kewirausahaan, Vol. 3, No. 1, pp.29-50.

Syaihu, A. (2012). Pengaruh Investasi Pemerintah Dan Investasi Swasta Terhadap Kesempatan Kerja Dan Pengangguran di Provinsi Kalimantan Timur, Jurnal Ekonomi Pembangunan, Vol. 10, No. 1, pp.1-32.

Todaro, P. M. (2000). Pembangunan Ekonomi di Dunia Ketiga. Jakarta: Penerbit Erlangga. 